\title{
EFFECT OF DETERGENTS ON ALKALINE INVERTASE AND ALKALINE PHOSPHATASE ACTIVITY OF FUNGI MUCOR PLUMBEUS Bonord, 1864, ASPERGILLUS NIGER Tiegh, 1867 AND TRICHODERMA HARZIANUM Rifai, 1969
}

\section{IVANA MATOVIĆ-PURIĆ ${ }^{*}$ ， TATJANA JAKŠIĆ ${ }^{2}$ TATJANA MIHAJILOV-KRSTEV ${ }^{3}$, PREDRAG VASIĆ ${ }^{2}$}

\author{
${ }^{1}$ Medical School, Čačak, Serbia \\ ${ }^{2}$ Department of Biology, Faculty of Sciences and Mathematics, University of Priština, Kosovska Mitrovica, Serbia \\ ${ }^{3}$ Faculty of Sciences and Mathematics, University of Niš, Niš, Serbia
}

\begin{abstract}
Due to their diverse metabolic potential, many filamentous fungi have a great ability for degradation of different waste substances. The present research was aimed to investigate ability of fungi Mucor plumbeus, Aspergillus niger and Trichoderma harzianum, isolated from sewer and industrial waste water, to conduct degradation of high concentrations of commercial detergent (0.3\%). Within enzyme extracts of samples taken during period of 3-16 days, activity of alkaline invertase and alkaline phosphatase was followed spectrophotometrically at room temperature. Obtained results proved that all examined fungi affected degradation of detergent. Quality (inhibition/stimulation) and quantity of action of detergent on activity of investigated enzymes depended on fungal species and incubation period. The highest inhibiting effect of detergent was recorded on $9^{\text {th }}$ day of incubation in samples of $T$. harzianum and $A$. niger, while its most obvious stimulating effect was noticed on $3^{\text {rd }}$ day of incubation in samples of $T$. harzianum and $M$. plumbeus. Investigated fungi can be used for purification of waste water containing high concentrations of detergent.
\end{abstract}

Keywords: Aspergillus niger, Mucor plumbeus, Trichoderma harzianum, Waste waters, Detergent, Alkaline invertase, Alkaline phosphatase.

\section{INTRODUCTION}

Increased use of detergents in households led to their accumulation in waste water and natural water ecosystems. It also caused numerous unfavorable consequences for microbiological community and hydro-bionics (Kumar et al., 2007; Chaturvedi \& Kumar, 2010; Abu-Zreig et al., 2003). As pollutants, detergents and their products of degradation, reach environment through industrial and sewer waste water, usage of pesticides and disposal of waste active mud (Cavalli, 2004; Ying, 2006).

Literature includes very few data related to degradation of commercial detergents under effect of fungi (Ojo \& Oso, 2008). It is known that products with high level of SASs (Surface Active Supstance) such as detergents, in water ecosystems can cause numerous harmful effects: they inhibite growth of one-cell seaweed, decelerate process of water purification by creation of foam, which delays dissolution of oxygen important for breathing and photosynthesis, and causes eutrophication. Many studies showed that tensides modify conformation of proteins and in such way enzyme activity, stability and specifity (Kamiya et al., 2000; Buvaneswari et al., 2013). Recent researches showed that filamentous fungi Myceliophthora thermophila, Geomyces sp., Alternaria alternata, Verticillium alboatrum, Aspergillus

\footnotetext{
* Corresponding author: matovic.puric.ivana@gmail.com
} BIOLOGY flavus, Trichoderma sp., Aspergillus oryzae, isolated from river mud are able to degrade different synthetic detergents of anion type (Ojo \& Oso, 2008). These fungi have specific apical growth, which provides ingrowth of hyphae into various substrates and excretion of extracellular enzymes. Under effect of these enzymes, complex organic compounds of substrates degrade into simplified compounds which can be absorbed by fungi through hyphae and used for growth (Raimbault, 1998; Saucedo-Castañeda et al., 1992; Raimbault, 1981). Filamentous fungus Mucor plumbeus produces different enzymes such as invertase, alkaline phosphatase, proteinase and lipase which are variously applied in biotechnology. Genus Aspergillus includes more than 180 species of fungi which present main decomposers of plant polysaccharides (Brookman \& Denning, 2000). Especially important species in biodegradation is Aspergillus niger which is commonly used due to its ability to produce different extracellular enzymes. Trichoderma spp. are saprophytic fungi which are located in soil and roots of plants but also highly metabolically valued (Saucedo-Castañeda et al., 1992). Trichoderma harzianum can decompose different compounds such as following: dichlorodipheniltrichloroethan (DDT), dieldrine, endosulphan, pentachloro-nitrobenzene (PCNB) and pentachlorophenol (PCP) (Brookman \& Denning, 2000). Species of Trichoderma have an important role in bioremediation of soil which is contaminated by pesticides, herbicides and insecticides (Brookman \& Denning, 2000). 
Invertases are enzymes which hydrolize disaharide sucrose to glucose and fructose. Invertases are isolated and defined in many filamentous fungi of species Penicillium, Neurospora, Aspergillus, etc. (Poonawalla et al., 1965; Ashok Kumar et al., 2001; Guimaraes et al., 2009). Most of fungi synthesize intracelullar and extracellular invertases (Gillespie et al., 1952; Crewther \& Lennox, 1953), which differ in the position within a cell (cell wall, vacuoles or cytoplasm), solubility (soluble or insoluble in buffer of a small ionic strength), optimum $\mathrm{pH}$ (acid or neutral/alkaline) and isoelectric point $(\mathrm{pI})$.

The aim of this research was to investigate ability of filamentous species Mucor plumbeus, Aspergillus niger and Trichoderma harzianum isolated from sewer and industrial waste water for degradation of high concentrations of commercial detergent $(0.3 \%)$ and to estimate their potentials for waste water purification.

\section{MATERIAL AND METHODS}

\section{Isolation of fungi from waste water}

Samples of waste water were collected using sterile glass bottles from three different localities (Sport Center 'Mladost', Industrial zone in Čačak and village Stančići) on the territory of the municipality of Čačak, during the end of May in 2013. After transport at temperature of $4{ }^{\circ} \mathrm{C}$, collected samples were sown in Petri dishes on Maltose agar (MA, Sigma Aldrich) which included streptomycin $(0,5 \mathrm{mg} / \mathrm{ml})$ for purpose of inhibition of bacteria growth. Sown samples were incubated at the room temperature during 5 days. After that, isolation of fungi into clean cultures was conducted on sterilized Potato Dextrose Agar (PDA, Sigma Aldrich) without streptomycin. Isolated individual species are identified on the base of macroscopic and microscopic morphology at Department for Biology and Ecology at the Faculty of Science University of Kragujevac, Serbia. All isolated fungi were cultivated until sporulation on tilted PDA at room temperature during 5-7 days. After that, isolated fungi were used for preparation of suspensions of spores in $10 \mathrm{ml}$ of sterile distilled water. Spores were counted under the microscope using Noebauer chamber in three repetition cycles, and their final concentration in inoculum was set on $10^{6}$ spores $\mathrm{ml}^{-1}$ (Stojanović et al., 2010).

\section{Enzymes extracts preparation}

Prepared suspension $(1 \mathrm{ml})$ of each investigated fungus was sown into two sterile Erlenmeyer flasks each containing $200 \mathrm{ml}$ of modified sterile Czapek Dox broth (CDB, pH value adjusted to 4.7 using $1 \mathrm{~mol} \mathrm{l}^{-1} \mathrm{HCl}$; Stojanović et al., 2010). After that, detergent (D) was added into one of two Erlenmeyer flasks to reach the final concentration $0.3 \% \quad(w / w)$. The second Erlenmeyer flask was used as a control (K). Both Erlenmeyer flasks with samples were incubated during 16 days at the room temperature on electric shaker (Kinetor, Ljubljana, Slovenia) on
$250 \mathrm{rpm}$. For further analysis samples were taken after 3, 6, 9, 12 and 16 days of incubation. The liquid in amount of $10 \mathrm{ml}$ was taken from each Erlenmeyer flask. This liquid was filtered through Whatman filter paper in order to remove traces of mycelia. After that, liquids were centrifuged for $10 \mathrm{~min}$ at 10,000 rpm, at the temperature of $+4{ }^{\circ} \mathrm{C}$ (Stojanović et al., 2010). Obtained supernatants were used as a raw enzyme extracts for defining of activity of enzymes of alkaline invertase and alkaline phosphatase. The experiment was conducted in three repetitions.

\section{Determination of alkaline invertase activity}

Invertase enzyme activity was determined by Sumner \& Howell method (1935). Firstly, reactive mixture was developed in two tubes. This mixture included following components: 0.5 $\mathrm{ml}$ of raw enzyme extract, $0.5 \mathrm{ml} 0.02 \mathrm{~mol}^{-1}$ of phosphate buffer ( $\mathrm{pH} \mathrm{8.0)} \mathrm{and} 1 \mathrm{ml} \mathrm{1 \% (w/w)} \mathrm{of} \mathrm{sucrose.} \mathrm{One} \mathrm{tube} \mathrm{(trial} \mathrm{one)} \mathrm{was}$ incubated in water bathroom at $37^{\circ} \mathrm{C}$ for $15 \mathrm{~min}$ and the second one (control) was placed on ice during the same period. After that, $1 \mathrm{ml}$ of mixture from each of tube was transferred into new tubes and $2 \mathrm{ml}$ of dinitrosalicylic reagent was added into each of them. Both tubes were then incubated at $100{ }^{\circ} \mathrm{C}$ for $5 \mathrm{~min}$. After cooling to the room temperature, the amount of reducing sugars was determined spectrophotometrically at absorbance of $540 \mathrm{~nm}$. The standard line was constructed using six tubes which contained $0.05,0.10,0.20,0.30,0.40$ and $0.50 \mathrm{ml}$ of standard solution of glucose $\left(1 \mathrm{mg} \mathrm{ml}{ }^{-1}\right.$ of solution of $5.56 \times 10^{-3} \mathrm{~mol}^{-1}$ glucose standard - Sigma Aldrich) in distilled water which was used as a base line. All tubes were incubated at $55^{\circ} \mathrm{C}$ for $20 \mathrm{~min}$. The results were presented as a mean value of three repetitions.

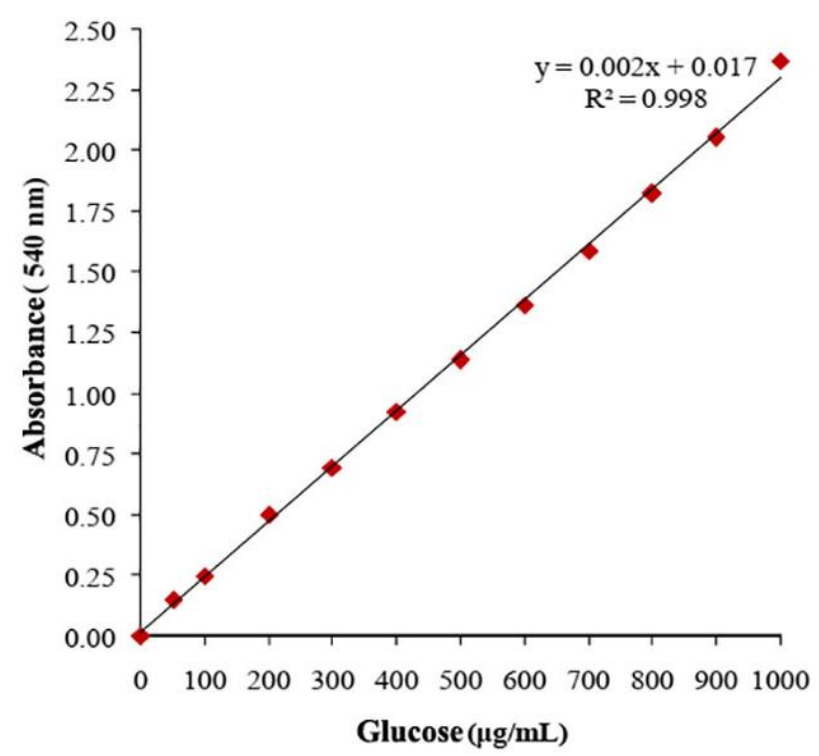

Figure 1. Standard line for glucose.

\section{Determination of alkaline phosphatase activity}

Enzyme activity of alkaline phosphatase was determined using the certain amount of inorganic phosphorus by Allen method according to Stojanović (2007). Enzyme activity was 
measured in reaction mixture prepared of $1 \mathrm{ml}$ of enzyme extract, $1 \mathrm{ml}$ of glycol buffer ( $\mathrm{pH} 9.0$ ) with $\mathrm{Mg}^{2+}$ and $1 \mathrm{ml}$ of $\beta$ glycerophosphate (substrate). Tubes with reactive mixture were incubated at $37^{\circ} \mathrm{C}$ for $30 \mathrm{~min}$, after which the enzyme reaction is stopped by adding $3 \mathrm{ml}$ of $10 \%$ trihydroxyuric acid (TCA). After that, tubes were held on ice for $15 \mathrm{~min}$, after which their content was filtrated and the filtrate was collected. Control tubes were prepared in the same way except the incubation process. The phosphorus concentration in samples was determined through Allen reaction. The amount of $1 \mathrm{ml}$ of filtrate for trial and $1 \mathrm{ml}$ of filtrate for control were measured in two tubes each. After that, $0.4 \mathrm{ml}$ of amido (Sigma Aldrich), $0.4 \mathrm{ml}$ of $60 \%$ TCA (Sigma Aldrich), $0.2 \mathrm{ml}$ of ammonium molybdate and $3 \mathrm{ml}$ of distilled water were added to each of tubes. Tubes were incubated at the room temperature for $11 \mathrm{~min}$. In order to construct standard line for phosphorus, the series of phosphorus standard solutions with lowered concentration were prepared and the described procedure was repeated. The measurement of absorbance was conducted at $720 \mathrm{~nm}$. The results were expressed as a mean value of three repetitions (Heinonen \& Lahti, 1981).

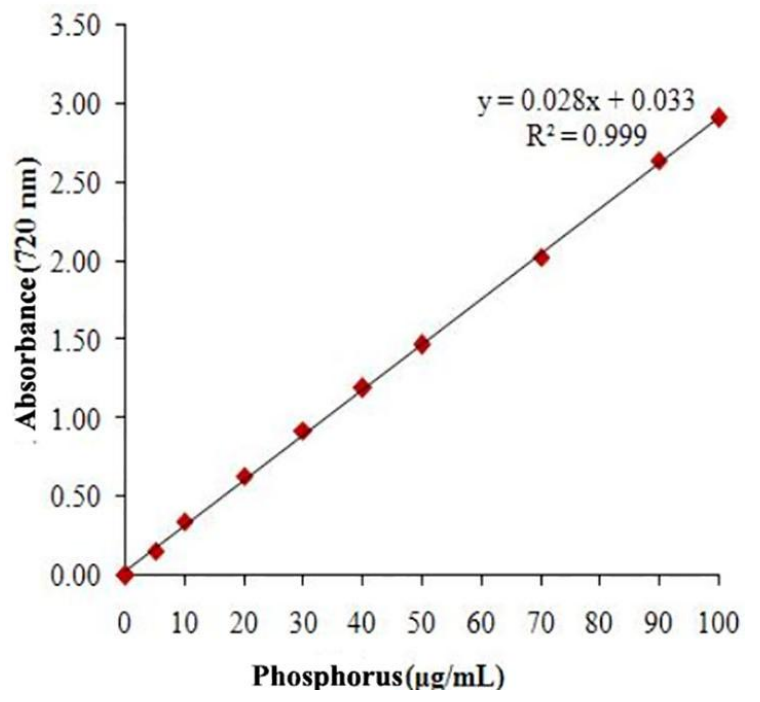

Figure 2. Standard line for phosphorus.

\section{Statistical analysis}

All experiments were performed in triplicate and results were expressed as means \pm standard error of mean. For statistical analysis, the following tests were used: Mann-Whitney and Kruskal-Wallis Tests. Values of $p<0.05$ were considered statistically significant.

\section{RESULTS AND DISCUSSION}

Results of many researches confirmed that activity of invertases depends on kind of surface and phase of development of fungi. Vainstein \& Peberdy (1991) proven that Aspergillus nidulans produces extracellular invertases when grown on medium containing sucrose or raffinose, and their enzyme maximum can be achieved after $15 \mathrm{~h}$ of incubation at $28{ }^{\circ} \mathrm{C}$. Poonawalla et al. (1965) concluded that Penicillium chrysogenum and Sascharomyces cerevisiae grown on medium with $30 \mathrm{~g} \mathrm{l}^{-1}$ sucrose in submerged fermentation produce intraand extracellular invertase with maximum activity of enzymes achieved between 72 and $96 \mathrm{~h}$.

In the present study we investigated activity of alkaline invertase and alkaline phosphatase in control medium (which included sucrose in the first case) and in the medium containing detergent. Summary results of the experiment are presented in the Table 1.

With the exception of alkaline phosphatase activity in $T$. harzianum, Mann-Whitney U Test indicated that the activity of both enzymes was significantly higher $(p<0.05)$ in detergent containing media than in control media (Table 2). Also, KruskalWallis Test showed statistically significant difference between enzymes activity in different fungi both on control media and detergent containing media (Table 3).

Activity of alkaline invertase of $M$. plumbeus (Table 1) in control medium was negligible on the $3^{\text {rd }}$ day of the experiment while it was almost totally inhibited on the $6^{\text {th }}$ day $\left(0.0082 \mathrm{IU} \mathrm{ml}^{-}\right.$ $\left.{ }^{1}\right)$. Sudden increasing of enzyme activity was recorded in a period from the $9^{\text {th }}$ to $16^{\text {th }}$ day, when it reached maximum value of 0.0883 $\mathrm{IU} \mathrm{ml}{ }^{-1}$. In case of medium containing $0.3 \%$ of detergent, the significantly higher activity of alkaline invertase was recorded. It did not change much during investigated time period and its enzyme maximum was reached on the $16^{\text {th }}$ day of the experiment $(0.1607$ IU $\mathrm{ml}^{-1}$ ) when the mycelium of fungus was totally developed.

Activity of alkaline invertase of A. niger (Table 1) in control medium was changeable. The maximum activity was recorded on the $3^{\text {rd }}$ day of incubation, after which its slope was recorded. It reached its minimum value on the $9^{\text {th }}$ day of the experiment $\left(0.0680 \mathrm{IU} \mathrm{ml}^{-1}\right)$. Activity of alkaline invertase in medium containing detergent was expressed during the entire period of mycelium growth, from the $3^{\text {rd }}$ to $9^{\text {th }}$ day, while maximum activity was measured at the $3^{\text {rd }}$ day of the experiment (3.7673 $\mathrm{IU} \mathrm{ml}^{-1}$ ).

Activity of alkaline invertase of $T$. harzianum (Table 1) in control medium was negligible till $9^{\text {th }}$ day of experiment, when it reached sudden increase of enzymes activity to their maximum value $\left(0.8097 \mathrm{IU} \mathrm{ml}^{-1}\right)$. In surface with detergent, the enzymes activity was the smallest on the $3^{\text {rd }}$ day of the experiment $(0.1620 \mathrm{IU}$ $\left.\mathrm{ml}^{-1}\right)$, while on the $6^{\text {th }}$ day it had sudden increase to its maximum value (3.4257 $\left.\mathrm{IU} \mathrm{m}^{-1}\right)$, which was measure on the $16^{\text {th }}$ day.

Phosphatases hydrolize esters and anhydrides of phosphoric acid. These enzymes are involved in various biological processes such as cell cycle, differentiation of cells and other cell processes. Optimum value of $\mathrm{pH}$ beeing 9 is needed for effect of alkaline phosphatase, while numerous researches showed that enzyme is active in wide range of $\mathrm{pH}$ being 3-9. Characteristics of acid and alkaline phosphatase in nutritive medium (extracellular enzymes) and mycelium extracts (citoplasmatic 
and cellular bonded enzymes) were investigated in different fungi grown in stationary conditions on liquid mineral medium (Raper \& Fennell, 1965). Many alkaline phosphatases have speciffic effects on substrate. Production of phosphatase of $A$. awamori var. kawachii was investigated in media with small or large concentration of phosphate. This fungus has maximum of phosphatase activity in medium with small concentration of phosphate, such as bake yeast, Escherichia coli and Neurospora crassa (Schmidt et al., 1956). On the other hand, in medium with high concentration of phosphate, phosphatase activity was weak but still higher with $\beta$-glycerosphate as substrate than with glucose-6-phosphate. Researche conducted by Koffi et al. (2010) showed that SDS detergent displays strong inhibitory effect (cca $98 \%$ ) on phosphatase activity.

Table 1. Activity of alkaline invertase and alkaline phosphatase ( $\mathrm{IU} \mathrm{ml}^{-1}$ ) in fungi M. plumbeus, A. niger and T. harzianum followed period of 3-16 days*.

\begin{tabular}{|l|c|c|c|c|c|c|}
\hline \multirow{2}{*}{ Sample } & \multicolumn{3}{|c|}{$\begin{array}{c}\text { Alkaline invertase } \\
\left(\mathrm{IU} \mathrm{ml}{ }^{-1}\right)\end{array}$} & \multicolumn{3}{c|}{$\begin{array}{c}\text { Alkaline phosphatase } \\
\left.(\mathrm{IU} \mathrm{ml})^{-1}\right)\end{array}$} \\
\cline { 2 - 7 } & M.plumbeus & A. niger & T. harzianum & M. plumbeus & A. niger & T. harzianum \\
\hline K-3 & $0.0273 \pm 0.0198$ & $3.5337 \pm 0.0024$ & $0.0410 \pm 0.0295$ & $0.1373 \pm 0.0033$ & $0.1043 \pm 0.0024$ & $0.4673 \pm 0.0050$ \\
\hline K-6 & $0.0082 \pm 0.0057$ & $0.1967 \pm 0.0038$ & $0.0623 \pm 0.0023$ & $0.3640 \pm 0.0026$ & $0.0317 \pm 0.0023$ & $0.0023 \pm 0.0009$ \\
\hline K-9 & $0.0220 \pm 0.0026$ & $0.0680 \pm 0.0029$ & $0.8097 \pm 0.0052$ & $0.5130 \pm 0.0087$ & $0.0857 \pm 0.0035$ & $1.8213 \pm 0.0064$ \\
\hline K-12 & $0.0430 \pm 0.0023$ & $0.3363 \pm 0.0033$ & $0.2870 \pm 0.0023$ & $0.0051 \pm 0.0004$ & $0.1343 \pm 0.0041$ & $0.4557 \pm 0.0091$ \\
\hline K-16 & $0.0883 \pm 0.0043$ & $0.9167 \pm 0.0035$ & $0.3340 \pm 0.0017$ & $0.6760 \pm 0.0061$ & $0.1733 \pm 0.0050$ & $0.7120 \pm 0.0040$ \\
\hline & & & & & \\
\hline D-3 & $0.1543 \pm 0.0024$ & $3.7673 \pm 0.0055$ & $0.1620 \pm 0.0032$ & $2.1987 \pm 0.0034$ & $0.2507 \pm 0.0018$ & $1.4467 \pm 0.2467$ \\
\hline D-6 & $0.1487 \pm 0.0043$ & $3.6140 \pm 0.0032$ & $0.9563 \pm 0.0041$ & $1.0943 \pm 0.0029$ & $0.3577 \pm 0.0029$ & $0.7607 \pm 0.0015$ \\
\hline D-9 & $0.1527 \pm 0.0026$ & $3.6777 \pm 0.0032$ & $0.5767 \pm 0.0043$ & $1.2490 \pm 0.0032$ & $0.0710 \pm 0.0017$ & $0.0061 \pm 0.0005$ \\
\hline D-12 & $0.1570 \pm 0.0021$ & $2.3010 \pm 0.0032$ & $0.8937 \pm 0.0041$ & $0.3510 \pm 0.0038$ & $0.7627 \pm 0.0020$ & $0.3170 \pm 0.0026$ \\
\hline D-16 & $0.1607 \pm 0.0035$ & $2.7010 \pm 0.0044$ & $3.4257 \pm 0.0041$ & $1.5840 \pm 0.0021$ & $0.4683 \pm 0.0033$ & $0.2613 \pm 0.0032$ \\
\hline
\end{tabular}

$* \mathrm{~K}$ - control samples without detergent (K3-K16); D - samples with addition of $0.3 \%(\mathrm{w} / \mathrm{w})$ detergent (D3-D16); results were expressed as means \pm standard error of mean

Table 2. Mann-Whitney U Test for comparison of alkaline invertase and alkaline phosphatase activity between control samples and samples with addition of detergent.

\begin{tabular}{|c|c|c|c|c|c|c|c|}
\hline & \multicolumn{4}{|c|}{ Ranks } & \multicolumn{3}{|c|}{ Test Statistics } \\
\hline & Group & $\mathrm{N}$ & $\begin{array}{c}\text { Means } \\
\left(\mathrm{IU} \mathrm{ml}^{-1}\right)\end{array}$ & $\begin{array}{l}\text { Sum of } \\
\text { Ranks }\end{array}$ & $\begin{array}{c}\text { Mann- } \\
\text { Whitney U }\end{array}$ & $\mathrm{Z}$ & p-level* \\
\hline \multirow{9}{*}{$\begin{array}{l}\text { Alkaline } \\
\text { invertase } \\
\text { activity }\end{array}$} & \multicolumn{7}{|c|}{ M. plumbeus } \\
\hline & Control & 15 & 0.0378 & 120.00 & \multirow{2}{*}{0.00} & \multirow{2}{*}{-4.66628} & \multirow{2}{*}{0.000003} \\
\hline & Detergent & 15 & 0.1547 & 345.00 & & & \\
\hline & \multicolumn{7}{|c|}{ A. niger } \\
\hline & Control & 15 & 1.0103 & 138.00 & \multirow{2}{*}{18.00} & \multirow{2}{*}{-3.91968} & \multirow{2}{*}{0.000089} \\
\hline & Detergent & 15 & 3.2122 & 327.00 & & & \\
\hline & \multicolumn{7}{|c|}{ T. harzianum } \\
\hline & Control & 15 & 0.3068 & 156.00 & \multirow{2}{*}{36.00} & \multirow{2}{*}{-3.17307} & \multirow{2}{*}{0.001508} \\
\hline & Detergent & 15 & 1.2029 & 309.00 & & & \\
\hline \multirow{9}{*}{$\begin{array}{l}\text { Alkaline } \\
\text { phosphatase } \\
\text { activity }\end{array}$} & \multicolumn{7}{|c|}{ M. plumbeus } \\
\hline & Control & 15 & 0.3391 & 147.00 & & & \\
\hline & Detergent & 15 & 1.2954 & 318.00 & 27.00 & -3.54631 & 0.000391 \\
\hline & \multicolumn{7}{|c|}{ A. niger } \\
\hline & Control & 15 & 0.1059 & 156.00 & \multirow{2}{*}{36.00} & \multirow{2}{*}{-3.17307} & \multirow{2}{*}{0.001508} \\
\hline & Detergent & 15 & 0.3821 & 309.00 & & & \\
\hline & \multicolumn{7}{|c|}{ T. harzianum } \\
\hline & Control & 15 & 0.6917 & 243.00 & \multirow{2}{*}{102.00} & \multirow{2}{*}{0.435520} & \multirow{2}{*}{0.663186} \\
\hline & Detergent & 15 & 0.5584 & 222.00 & & & \\
\hline
\end{tabular}

*Values of $\mathrm{p}<0.05$ were considered statistically significant 
Activity of alkaline phosphatase of investigated fungi in control medium and in medium containing detergent is also presented in Table 1. In control medium, activity of alkaline phosphatase of $M$. plumbeus (Table 1) was significantly increased in period of mycelium growth $\left(3^{\text {rd }}\right.$ to $9^{\text {th }}$ day) after which its sudden decrease appeared to negligible value $(0.0051$ $\mathrm{IU} \mathrm{ml}{ }^{-1}$ ) measured on the $12^{\text {th }}$ day. In medium with detergent enzyme activity varied from maximum value on the $3^{\text {rd }}$ day of the experiment $\left(2.1987 \mathrm{IU} \mathrm{ml}^{-1}\right)$ to minimum value on the $12^{\text {th }}$ day of experiment $\left(0.3510 \mathrm{IU} \mathrm{ml}^{-1}\right)$ after which it increased till $16^{\text {th }}$ day of the experiment $\left(1.5840 \mathrm{IU} \mathrm{ml}^{-1}\right)$.
Activity of alkaline phosphatase of A. niger in control medium decreased from the $3^{\text {rd }}$ to $6^{\text {th }}$ day. It was totally inhibited by $6^{\text {th }}$ day. Enzyme maximum of A. niger in control medium was reached on the last day of the experiment $\left(0.1733 \mathrm{IU} \mathrm{ml}^{-1}\right)$. In medium with detergent, the enzyme activity has been increased during development of fungi mycelium. Significant decreasing of enzyme activity was recorded on $9^{\text {th }}$ day $\left(0.0710 \mathrm{IU} \mathrm{ml}^{-1}\right)$, while the highest increase in activity was recorded on the $12^{\text {th }}$ day $\left(0.7627 \mathrm{IU} \mathrm{ml}^{-1}\right)$. Presence of detergent in medium stimulated activity of alkaline phosphatase compared to control nutritive medium.

Table 3. Kruskal-Wallis ANOVA by Ranks for comparison of alkaline invertase and alkaline phosphatase activity among fungi M. plumbeus, A. niger and T. Harzianum.

\begin{tabular}{|c|c|c|c|c|c|c|c|}
\hline & \multicolumn{4}{|c|}{ Ranks } & \multicolumn{3}{|c|}{ Test Statistics } \\
\hline & Group & $\mathrm{N}$ & $\begin{array}{c}\text { Means } \\
\left(\mathrm{IU} \mathrm{ml}^{-1}\right)\end{array}$ & $\begin{array}{l}\text { Sum of } \\
\text { Ranks }\end{array}$ & $\mathrm{H}(2)$ & Total N & p-level* \\
\hline \multirow{8}{*}{$\begin{array}{l}\text { Alkaline } \\
\text { invertase } \\
\text { activity }\end{array}$} & \multicolumn{7}{|c|}{ Control samples } \\
\hline & M. plumbeus & 15 & 0.0378 & 164.00 & & & \\
\hline & A. niger & 15 & 1.0103 & 489.50 & 21.24720 & 45 & 0.0000 \\
\hline & T. harzianum & 15 & 0.3068 & 381.50 & & & \\
\hline & \multicolumn{7}{|c|}{ Samples with addition of detergent } \\
\hline & M. plumbeus & 15 & 0.1547 & 126.50 & & & \\
\hline & A. niger & 15 & 3.2122 & 552.00 & 35.07609 & 45 & 0.0000 \\
\hline & T. harzianum & 15 & 1.2029 & 356.50 & & & \\
\hline \multirow{8}{*}{$\begin{array}{l}\text { Alkaline } \\
\text { phosphatase } \\
\text { activity }\end{array}$} & \multicolumn{7}{|c|}{ Control samples } \\
\hline & M. plumbeus & 15 & 0.3391 & 369.00 & & & \\
\hline & A. niger & 15 & 0.1059 & 222.00 & 9.857391 & 45 & 0.0072 \\
\hline & T. harzianum & 15 & 0.6917 & 444.00 & & & \\
\hline & \multicolumn{7}{|c|}{ Samples with addition of detergent } \\
\hline & M. plumbeus & 15 & 1.2954 & 511.50 & & & \\
\hline & A. niger & 15 & 0.3821 & 251.00 & 16.16232 & 45 & 0.0003 \\
\hline & T. harzianum & 15 & 0.5584 & 272.50 & & & \\
\hline
\end{tabular}

*Values of $\mathrm{p}<0.05$ were considered statistically significant

Activity of alkaline phosphatase of $T$. harzianum in control medium was totally inhibited on the $6^{\text {th }}$ day, after which an increase was recorded. Maximum of enzyme activity was measured on the $9^{\text {th }}$ day $\left(1.8213 \mathrm{IU} \mathrm{ml}^{-1}\right)$. However, in the stage of autolysis ( $12^{\text {th }}$ day), the activity was near to the value recorded on the $3^{\text {rd }}$ day $\left(0.4673 \mathrm{IU} \mathrm{ml}^{-1}\right)$. In medium with detergent, the enzyme activity was changeable. Enzyme maximum was recorded on the $3^{\text {rd }}$ day $\left(1.4461 \mathrm{IU} \mathrm{ml}^{-1}\right)$, after which a decrease of enzyme activity was recorded. It was inhibited on the $9^{\text {th }}$ day and reached its minimum value $\left(0.0061 \mathrm{IU} \mathrm{ml}^{-1}\right)$.

\section{CONCLUSION}

Effect of detergent on alkaline invertase and alkaline phosphatase activity of Mucor plumbeus, Aspergillus niger and Trichoderma harzianum was significantly different during experimental period of 16 days. In control medium, the lowest activity of alkaline invertase was recorded in $M$. plumbeus during the entire experimental period while maximum of enzyme activity was reached in A. niger ( $3^{\text {rd }}$ day) and T. harzianum $\left(16^{\text {th }}\right.$ day). In the medium containing detergent, activity of alkaline invertase was stimulated or inhibited depending on fungal species. The highest stimulating effect of detergent was related to activity of alkaline invertase of $A$. niger ( $3^{\text {rd }}$ day) and $T$. harzianum $\left(16^{\text {th }}\right.$ day). Inhibitory effect of detergent was recorded for enzyme activity of $M$. plumbeus (during the entire experiment period) and $T$. harzianum ( $3^{\text {rd }}$ day). In control medium, the activity of alkaline phosphatase was the lowest in T. harzianum ( $6^{\text {th }}$ day), but the same fungus reached the highest enzyme activity on $9^{\text {th }}$ day. Detergent had stimulatory or inhibitory effect on this enzyme, mostly depending on fungal species. The strongest inhibitory effect of detergent was recorded in enzyme activity of $T$. harzianum $\left(9^{\text {th }}\right.$ day) and A. niger $\left(9^{\text {th }}\right.$ day). Stimulatory effect of detergent was recorded for enzyme activity of M. plumbeus ( $3^{\text {rd }}$ day) and T. harzianum ( $3^{\text {rd }}$ day).

Obtained results are important for possible practical application of mentioned fungus species in processes of waste 
water purification and production of enzymes for use in chemical industry. Based on comparison of enzyme activity of different fungi in detergent containing media we can recommend $M$. plumbeus for waste water treatment due to high alkaline phosphatase activity as well as A. niger due to high alkaline invertase activity.

\section{REFERENCES}

Abu-Zreig, M., Rudra, R. P., \& Dickinson, W. T. 2003. Effect of Application of Surfactants on Hydraulic Properties of Soils. Biosystems Engineering, 84(3), pp. 363-372. doi:10.1016/s1537-5110(02)00244-1

Ashokkumar, B., Kayalvizhi, N., \& Gunasekaran, P. 2001. Optimization of media for $\beta$-fructofuranosidase production by Aspergillus niger in submerged and solid state fermentation. Process Biochemistry, 37(4), pp. 331-338. doi:10.1016/s0032-9592(01)00204-7

Brookman, J. L., \& Denning, D. W. 2000. Molecular genetics in Aspergillus fumigatus. Current Opinion in Microbiology, 3(5), pp. 468-474. doi:10.1016/s1369-5274(00)00124-7

Buvaneswari, S., Damodarkumar, S., \& Murugesan, S. 2013. Bioremediation studies on sugar-mill effluent by selected fungal species. International Journal of Current Microbiology and Applied Sciences, 2, pp. 50-58.

Cavalli, L. 2004. Environmental impact, surfactant science series. Part B. In U. Zoller Ed., Handbook of Detergents. New York: Marcel Dekker, 121, pp. 373-427.

Chaturvedi, V., \& Kumar, A. 2010. Toxicity of sodium dodecyl sulfates in fishes and animals. International Journal of Applied Biology and Pharmaceutical Technology, 1, pp. 630633.

Crewther, W., \& Lennox, F. 1953. Enzymes of Aspergillus Oryzae III. The Sequence of Appearance and Some Properties of the Enzymes Liberated During Growth. Australian Journal of Biological Sciences, 6(3), p. 410. doi:10.1071/bi9530410

Gillespie, J. M., Jermyn, M. A., \& Woods, E. F. 1952. Multiple Nature of the Enzymes of Aspergillus Oryzæ and of HorseRadish: Enzymes of Aspergillus oryzae. Nature, 169(4299), pp. 487-488. doi:10.1038/169487a0

Guimarães, L. H. S., Somera, A. F., Terenzi, H. F., Polizeli, M. d. T. d., \& Jorge, J. A. 2009. Production of $\beta$ fructofuranosidases by Aspergillus niveus using agroindustrial residues as carbon sources: Characterization of an intracellular enzyme accumulated in the presence of glucose. Process Biochemistry, 44(2), pp. 237-241. doi:10.1016/j.procbio.2008.10.011

Heinonen, J. K., \& Lahti, R. J. 1981. A new and convenient colorimetric determination of inorganic orthophosphate and its application to the assay of inorganic pyrophosphatase. Analytical Biochemistry, 113(2), pp. 313-317.

doi:10.1016/0003-2697(81)90082-8
Kamiya, M., Judson, H., Okazaki, Y., Kusakabe, M., Muramatsu, M., Takada, S., Takagi, N., Arima, T., Wake, N., Kamimura, K., Satomura, K., Hermann, R., Bonthron, D. T. \& Hayashizaki, Y. 2000. The cell cycle control gene ZAC/PLAGL1 is imprinted--a strong candidate gene for transient neonatal diabetes. Human Molecular Genetics, 9(3), pp. 453-460. doi:10.1093/hmg/9.3.453

Koffi, D., Faule, B., Gonnety, J., Bédikou, M., Kouamé, L., Zoro, I., \& Niamké, S. 2010. Biochemical characterization of phosphatase, $\beta$-galactosidase and $\alpha$-mannosidase activities of seeds of an oleaginous cucurbit: Lagenaria siceraria (Molina) Standl blocky-fruited cultivar. Sciences and Nature, 7(2). doi:10.4314/scinat.v7i2.59966

Kumar, M., Trivedi, S. P., Misra, A., \& Sharma, S. 2007. Histopathological changes in testis of the freshwater fish Heteropneustes fossilis (Bloch) expos to linear alkyl benzene sulphonate (LAS). Journal of Environmental Bioogy, 28, pp. 679-684.

Ojo, O. A., \& Oso, B. A. 2008. Isolation and characterization of synthetic detergent-degraders from waste water. African Journal of Biotechnology, 7, pp. 3753-3760.

Poonawalla, F. M., Patel, K. L., \& Iyengar, M. R. S. 1965. Invertase production by Penicillium chrysogenum and other fungi in submerged fermentation. Applied and Environmental Microbiology, 13, pp. 749-754.

Raimbault, M. 1981. Fermentation en milieu solide: Croissance de champignons filamenteux sur substrats amylacés. Paris: Orstom. Série Travaux et Documents.

Raimbault, M. 1998. General and microbiological aspects of solid substrate fermentation. Electronic Journal of Biotechnology, 1(2), pp. 174-188. doi:10.2225/vol1-issue3fulltext-9

Raper, K. B., \& Fennell, D. I. 1965. The genus Aspergillus. Baltimore: William and Wilkins.

Saucedo-Castañeda, G., Lonsane, B. K., Navarro, J. M., Rogssos, S., \& Raimbault, M. 1992. Potential of using a simple fermenter for biomass built up, starch hydrolysis and ethanol production: Solid state fermentation system involving Schwanniomyces castellii. Applied Biochemistry and Biotechnology, 36(1), pp. 47-61. doi:10.1007/bf02950774

Saucedo-Castaneda, G., Lonsane, B. K., Krishnaiah, M. M., Navarro, J. M., Roussos, S., \& M. Raimbault, 1992. Maintenance of heat and water balances as a scale-up criterion for the production of ethanol by schwanniomyces castellii in a solid state fermentation system. Process Biochemistry, 27(2), pp. 97-107. doi:10.1016/00329592(92)80016-v

Schmidt, G., Seraidarian, K., Greenbaum, L. M., Hickey, M. D., \& Thannhauser, S. J. 1956. The effects of certain nutritional conditions on the formation of purines and of ribonucleic acid in baker's yeast. Biochimica et Biophysica Acta, 20, pp. 135149. doi:10.1016/0006-3002(56)90272-4 
Stojanović, J. 2007. Praktikum iz biohemije. Kragujevac: Prirodno-matematički fakultet.

Stojanović, J., Jakovljević, V., Matović, I., Mijušković, Z., \& Nedeljković, T. 2010. The influence of detergents, sodium tripoly-phosphates and ethoxyled oleyl-cetyl alcohol on metabolism of the fungi Penicillium verrucosum peyronel. Acta veterinaria, 60(1), pp. 67-77. doi:10.2298/avb1001067s

Sumner, J. B., \& Howell, S. F. 1935. A method for determination of saccharase activity. The Journal of Biological Chemistry, 108, pp. 51-54.

Vainstein, M. H., \& Peberdy, J. F. 1991. Regulation of invertase in Aspergillus nidulans: effect of different carbon sources.
Journal of General Microbiology, 137(2), pp. 315-321. doi:10.1099/00221287-137-2-315

Ying, G. 2006. Fate, behavior and effects of surfactants and their degradation products in the environment. Environment International, 32(3), pp. 417-431.

doi:10.1016/j.envint.2005.07.004 